\title{
A study about the characteristics of the contemporary parental exercise and care network
}

\section{Um estudo acerca das características do exercício parental contemporâneo e a respectiva rede de cuidados}

\author{
Nathalia Teixeira Caldas CAMPANA' ${ }^{1}$ [D 0000-0002-1100-7166 \\ Isabel Cristina GOMES1 (iD) 0000-0001-9335-9706
}

\begin{abstract}
Considering the transformations that have occurred in the ways contemporary families operate, we propose an investigation on how heterosexual couples understand and exercise parenting, as well as on how they deal with the child care network. Based on qualitative methodology, 8 couples and their children's pediatricians and educational coordinators were interviewed. The analysis of the results covered two categories: (1) The Construction of Parenthood and Care Network, and (2) Parental Exercise. Interviews were analyzed based on the perspective of psychoanalysis and psychosocial studies. We identified three possibilities for parenthood appropriation: (a) greater fluidity in parental roles, (b) egalitarian parental care, in which a greater value was assigned to the maternal figure, especially in the discourse made by parents and; (c) disruption with gender binarism in the parental exercise, but with a predominance of the responsibility for child care assigned to one of the spouses. As for sharing child care related tasks, both pediatricians and schools were seen as important parental tools.
\end{abstract}

Keywords: Childhood; Gender; Parenthood.

\section{Resumo}

Diante das transformações que ocorreram no funcionamento das familias contemporâneas, o presente estudo propõe uma investigação acerca de como casais heterossexuais compreendem e exercem a parentalidade, e de como lidam

\footnotetext{
$\nabla \nabla \nabla \nabla$

1 Universidade de São Paulo, Instituto de Psicologia, Departamento de Psicologia Clínica. Av. Professor Mello de Morais, 1721, Butantã, 05508-030, São Paulo, SP, Brasil. Correspondência para/Correspondence to: N.T.C. CAMPANA. E-mail: <nacampana@gmail.com>. Support: Fundação de Amparo à Pesquisa do Estado de São Paulo (Foundation of the State of São Paulo) (Processes n². 2015/03045-0, 2018/13403-0).

Article based on the thesis of N.T.C. CAMPANA, entitled "Um estudo sobre a parentalidade contemporânea e a rede de cuidados com a primeira infância". Universidade de São Paulo, 2018.

$\nabla \nabla \nabla$

Como citar este artigo/How to cite this article

Campana, N. T. C., \& Gomes, I. C. (2019). A study about the characteristics of the contemporary parental exercise and care network. Estudos de Psicologia (Campinas), 36, e190028. http://dx.doi.org/10.1590/1982-0275201936e190028
} 
com a rede de cuidados. A pesquisa, de metodologia qualitativa, entrevistou oito casais, assim como os pediatras e coordenadores educacionais de seus filhos. A análise dos resultados abrangeu duas categorias: (1) Construção da parentalidade e rede de cuidados, e (2) Exercício parental. As interpretações fundamentaram-se na psicanálise e nos estudos psicossociais. Identificaram-se três possibilidades de apropriação da parentalidade: (a) maior fluidez nos papéis parentais, (b) cuidado parental igualitário, com predomínio, no discurso dos pais, de atribuição de maior valor à figura materna; e c) rompimento com o binarismo de gênero no exercício parental, mas com predomínio da responsabilidade de um dos cônjuges em relação aos cuidados com os filhos. Quanto ao compartilhamento dos cuidados, tanto pediatras quanto as escolas foram referidos como importantes auxiliares dos pais.

Palavras-chave: Infância; Gênero; Parentalidade.

The Brazilian nuclear family model, of a heterosexual couple with children and specific and clearly delimited gender divisions, consolidated in Brazil in the postcolonial period, has undergone a series of transformations in recent years (Gomes \& Levy, 2009). From the seventies on, with the woman leaving the house to join the labor market and the possibility of birth control, the search for the establishment of equal rights between husband and wife became an assumption in a lot of marital relations.

It is true that, at present, the nuclear family model persists because we are influenced by the models that precede us. But, considering the many changes that the family model has gone through in its structure and relational dynamics (Campana, Santos, \& Gomes, 2017), we ask ourselves: How do parents, in contemporary times, understand and exercise their parental role?

Although women today no longer have to fully surrender to motherhood, we still find echoes of the social values of the nineteenth and twentieth centuries that manifest themselves in the family, and broader social life aspects and the field of psychological and/or psychoanalytic theories. Even if the multiplicity of paths that a woman's desire can lead to is currently recognized, and society goes further in the understanding that maternal love is the product of a social construct (Badinter, 2011; Chodorow, 1978/2002), there is still the idea that, just by becoming a mother, maternal love will be then naturally born. Psychoanalysis itself, since its inception by Freud, has reinforced social places according to gender, having as its model the traditional family in which the man was fundamentally restricted to the role of family provider and supporter for the mother, who takes care of the baby (Freud, 1908/1996; Winnicott, 1956/2000).

We then take two inseparable dimensions to think about the construction of parenthood of men and women in contemporary times: the one which is constituted from the life story and the unique responses produced by the subjects plus what is part of the social field, and, in this sense, it is necessary to contextualize some issues that have emerged.

Campana and Gomes (2017) found that there is a constant tension of parents trying to reconcile their own pace with their children's pace. Becoming a father and a mother in general means renouncing oneself, so the question seems to be in terms of how to deal with renunciations and to distinguish between those consistent with the individual story and those corresponding to social demands, the latter might buffer the possibility for a parental creative living.

Deepening into the study of family dynamics and their implications for the parental exercise, we observe a growing production of articles that discuss this issue. In order to verify how the project of having children is discussed in the current scientific community, Biffi and Granato (2017) conducted a systematic review of articles published between 2009 and 2014 about this subject and found four main themes to be highlighted: the choice whether or not to have children; the male participation in child care; the establishment of conditions that configure the right moment to have a child and the conflicts and ambivalences that permeate this process of choice.

Santos, Campana, and Gomes (in press) also conducted a literature review study to discuss the construction of the concept of egalitarian parental care as a representation of a new dynamics of parent/ 
child relationship functioning. We found 64 Brazilian articles and 193 international articles that somehow addressed issues related to the current exercise of parenting, and based on their analysis, four themes were found: assumptions for an egalitarian ideal of family; contemporary parenting; parenting versus work versus professional career; and egalitarian parenting.

In general, articles on new ways of parenting in the context of heterosexual families point to an increase in the number of double-career couples - in which both spouses have a career and are dedicated to it, and suggest changes in the way parents exercise their parenting roles. As a result of the absence of parents who are increasingly engaged in work, the literature indicates that fathers and mothers feel responsible for monitoring their children (Amazonas, Vieira, \& Pinto, 2011) and, so that they can dedicate themselves to their own careers without undermining the care of their children, they resort to surrogates in the family or support network (nurseries and nannies). This form of child care is not without conflict, mainly due to the difficulty that some women find in giving up the traditional maternal role.

Although the role of the father is not as prominent in the literature as the role of the maternal figure, we found a prevalence of articles discussing the "new father" or the participatory father. The study by Moraes (2017) about the transition to paternity brings an important contribution to the theme in its understanding of child care, in the sense of primary maternal concern, can be exercised by men, provided they are available to an active adaptation to the baby's needs. In the same perspective, Santos and Antúnez (2018) consider the possibility of constituting a paternal holding in the direct care offered to the baby, in the period of absolute dependence, and understand that it is necessary to review aspects of Winnicott's theory facing the relational dynamics of contemporary families.

The studies that show a greater paternal participation in the direct care of the baby do not clarify whether this would be a restricted trend for double-career couples or if it would be an ongoing phenomenon, regardless of whether or not women pursue a professional career. On the other hand, the tendency to postpone the moment of having a child so that both partners can devote more time to their profession and to themselves, without the obligations that parenthood imposes, appears in the literature as a result of the professional career exercised by both spouses (Oliveira, Passos, Leal, \& Nascimento, 2013).

Another particularity that is specifically attributed to double-career couples is the dependence on social support in the form of institutions and professionals for outsourcing child care - dynamics in which the family relationship is maintained, but the role of educating is passed on to other people (Martins Filho, 2008). In this context, the author questioned how much, in terms of affection, respect and education, these professionals can devote to children. And he found that the family universe of grandparents, uncles and cousins is increasingly distanced and, with that, the parental exercise becomes a more solitary process. For dual-career couples, parenting can be experienced in terms of tasks - such as taking the child to day care, putting the child on the school bus and tucking the child in at night - in a routine with few moments of spontaneous and pleasant interaction, the result of a busy life and no time for reflection and planning.

The so-called outsourcing of care is also discussed in the literature in terms of what, in psychoanalytic theory, we call the paternal function. In a context in which the paternal function - of authority, rules and limits -, is transferred to institutions and the State (Lima \& Resende, 2013), there is a lack of hierarchy between parents and children in the way of establishing family relationships in the contemporary world (Zanetti \& Gomes, 2009). In this way, parents expect to receive help from their social circle to perform the parental function mainly to provide limits and deal with the child's frustration - a fundamental experience for the healthy development of the child's psyche.

As a counterpoint, it is necessary to remember that throughout the history of civilizations, children have always been the reason behind the creation of care networks because they need a greater amount of investment than their parents could dedicate to them (Vorcaro \& Ferreira, 2014). Aching and Granato (2018) 
highlight the importance of the support network in the experience of motherhood and the development of the mother-child relationship, as loneliness and helplessness defy maternal skills, while resilience and proper reception allow for the construction of a support network that favors a good enough motherhood.

If the way parents interpret the world and act has changed significantly since the emergence of psychoanalysis - when the rigidity of the patriarchal ideology prevailed -, it is justified that we undertake a study in order to understand the contemporary environment of young children, taking parents and the professionals who take care of the baby as representatives of the current social discourse.

This article, based on a PhD thesis, aims to discuss the results of an investigation into how heterosexual couples understand and exercise parenthood, as well as how they deal with the care network.

\section{Method}

This research followed the qualitative methodology proposed by Turato (2003) to describe and understand these human phenomena sense and meaning relationships. The theoretical basis was psychoanalytic and psychosocial, based on studies on child development, parent-child interactions, contemporary family configurations and the deconstruction of stereotypes regarding gender-related parental roles.

Eight heterosexual couples belonging to the Brazilian upper class (with a monthly income of approximately 10 minimum wages - BRL 9,980.00/USD 2,457.00, date of conversion: 9/6/2019) participated in the study, given that the phenomenon studied is concentrated in this population and differs from the experience of couples from other social classes. These couples were in an age range between 30 and 40 years, with complete higher education and with their first-born being under the age of three years. The children had no history of organic problems that could interfere with child development and, consequently, in the process of parenthood building.

In addition to the couples, the 8 pediatricians who cared for the participants' children and the 6 educational coordinators of the schools attended by the children were interviewed - two children were not enrolled in the day care center at the time of the interview. We prioritized getting to know the network of professionals of each family, without stating that it should necessarily be composed of pediatric and day care professionals.

\section{Procedures}

The couples were interviewed at their households. By collecting the research data in the subjects' natural environment, in the context of a face-to-face relationship with the participants, the affective exchanges mobilized while listening to the subjects' discourses were valued. The educators, for their part, were interviewed in a room inside the school premises, and the pediatricians in their private offices or clinics. The interviews with the couples had a maximum length of two hours, and the interviews with the professionals had a maximum length of one hour. The criterion adopted to end the research was the detection of saturation or repetition in the collected material.

The couples and the respective professionals were interviewed only once, based on a thematic guide/ script prepared by the researchers. The interviews were recorded and, after each of them, the researcher made a list of the impressions and feelings aroused during the process. After this first registration, the material was transcribed in full. Subsequently, a report of each interview containing all the collected data was elaborated. 
To perform the content analysis, the interviews were recorded and transcribed in full, as proposed by Bardin (1977); This article emphasizes the theoretical basis of psychosocial and psychoanalytic studies and the literature review. The research project was approved by the Human Research Ethics Committee of the Institute of Psychology of the University of São Paulo - Certificado de Apresentação para Apreciação Ética (CAAE, Certificate of Submission for Ethical Appreciation) No. 42434815.9.0000.5561.

\section{Results}

The results of the interviews were analyzed in two different categories: 1) Parenting Construction and Care Network and 2) Parental Exercise. Instead of using their real names, all families were assigned numbers from 1 to 8 and the identification data were modified to preserve the participants' identities. Family (1): Father (35 years old, business administrator). Mother (37 years old, chef). Baby: 7 months old. Family (2): Father (36 years old, engineer). Mother (37 years old, hotelier - though she never exercised her profession). Baby: 11 months old. Family (3): Father (38 years old, economist). Mother (36 years old, personal stylist). Baby: 18 months old. Family (4): Father (40 years old, psychologist). Mother (36 years old, chemist). Baby: 32 months old. Family (5): Father (37 years old, psychiatrist). Mother (33 years old, psychiatrist). Baby: 36 months old. Family (6): Father (31 years old, economist). Mother (31 years old, physiotherapist). Baby: 8 months old. Family (7): Father (36 years old, engineer). Mother (36 years old, engineer), Babies: 36 and 4 months old. Family (8): Father (35 years old, photographer). Mother (33 years old, advertiser). Babies: Twins 24 months old.

\section{Parenting Construction}

We observed that couples experience a transition from a relationship model that preached more rigid gender roles (nuclear family model) to another that presupposes more flexible relationships between spouses. Before becoming fathers and mothers, except for Couple 2, the spouses stated that there was a balance between them in terms of career and hours of domestic service. However, with the arrival of the child, the couple's dynamics changed - women became the main responsible for the children and the house, and men became the main family providers, except for families 7 and 8.

Specifically regarding family 7 , we found that the couple established an egalitarian routine in which both the husband and the wife were committed to taking care of children and with the financial provision. We concluded that couples exercised equal parental care as both spouses were available for it - both men and women were participative, and the mother did not have to coordinate or guide the husband on how to take care of the child. This father expressed his own initiative, not waiting for his wife's commands to act with the children.

In family 8, we observed a parental exercise that broke with the binarism of gender roles, not only because men were primarily responsible for daily child care practices, but also because we found a fluidity between male and female characteristics in the parental exercise of both members of the couple. Thus, while the mother nursed her children, fostered them, is affectionate and sensitive, she is also absent most of the day because she has work and is the family's financial provider. The father, in turn, is the one who is in charge of all daily care practices of their babies, but at the same time is firm and establishes several rules/ laws with his children.

With the entry into parenting, only one father (family 8) reported having interrupted his career to devote himself to taking care of his child. He even mentioned that he had this idea even before his wife 
got pregnant, because he had been predominantly raised by his father. All the other fathers had 5 days of paternity leave, either for being self-employed or for being in compliance with the paternity leave provided by the institutions in which they worked.

The father of family 2, due to his wife's postpartum health problems, took 45 days of leave to take care of her and the baby. The fact that this father took care of his child in the early days of the baby's life not only made parent-child bonding possible, but it seemed to us - along with other elements of his discourse -, to have allowed the father to establish primary concern - what Winnicott described as primary maternal concern in mothers.

All women interviewed interrupted their careers to take care of their babies in the first months of the baby's life, but self-employed women were the ones who were on leave - unpaid leave -, for less time: between 2 and 3 months (families 5 and 6 , respectively). Mother 4 interrupted her career for a year, without being paid or receiving a salary, to devote herself to motherhood, while the others who interrupted their careers and returned to work six months later were on paid leave by their employers.

None of the women mentioned leaving their careers because of motherhood, but we observed the influence of motherhood in delaying the resumption of the careers for the women of families 3 and 4 . In family 3, the money originating from the woman's work is considered by the couple as a complement of family income, a money that is not essential for them, which is why the couple decided by consensus that the woman could stop working to dedicate herself exclusively to motherhood. This couple established in their discourse a direct relationship between maternal presence and the development of a child's sense of security. In family 4, the woman's remuneration was not considered fundamental for family support either, but she considered it important to have her own source of income. In this case, the experience of motherhood relativized career satisfaction and, as the couple did not really need the money, the woman was even more exposed to ambivalent feelings. Her husband had to help her in this process by insisting that she resumed work and thus have more personal satisfaction.

In general, the career of men was approached by couples as an indisputable and unquestionable fact. Except for the men in families 7 and 8, most did not mention whether they should or would interrupt their careers to devote themselves exclusively to fatherhood, nor did they ask themselves whether they were satisfied with their professional life. Overall, paternal work was viewed by subjects as a hindrance to being more present in their children's routine during the week, but the men in families 3, 4 and 6 said that after the birth of their children, they came back home earlier by limiting career hours. families 1, 2 and 5, on the other hand, did not speak of any change in their work routines after becoming parents. None of these fathers had a fixed obligation in their child's routine during the week - they participated it by giving them a bath or food, for example, if they could get home early. Thus, however much, in their discourse, they showed goodwill to take care of their children, the responsibility was actually of the mother.

We found a greater conflict between trying to balance motherhood, the need to work for the income and wanting to work for personal satisfaction in the experiences reported by women. Except for the woman of family 2, who had never worked outside home, they all reported, with more or less guilt, finding satisfaction in working - what varied between them was the way they were experiencing motherhood. The idealization of motherhood and unconditional love emerged in the discourse of women of families 3, 4 and 6 , which seems to have contributed to their increased sense of guilt and self-esteem. The other mothers reported that, even before getting pregnant, they already questioned motherhood and thought about the challenges they would have to face.

Women who were more ambivalent about returning to their jobs (families 1, 3 and 4) were also the ones who were most emotional during the interview and showed more insecurity regarding motherhood. 6 In addition, they seemed to have reframed the importance and gratification they felt with their professions 
after they became mothers. The other women (families 5, 6, 7 and 8) were determined, even with some ambivalence, to return to work - in their reports, their jobs appeared as a necessity to maintain mental health, as they said they felt that living exclusively for motherhood meant a downgrade to their personal lives and an indiscriminate affection towards the baby. In their discourses, the experience of motherhood appeared linked to a feeling of helplessness, opposite to what they felt when thinking about their careers.

Whether or not women had a career did not directly interfere with the parenting behaviors of men. In family 2, even though the couple was structured on a more traditional family model, as mentioned earlier, it seemed to us that the man established the state of primary concern. In family 5, with the spouses exercising the same professional activity, the husband's career was prioritized because the woman was more psychically available for exercise parenting than her husband - he said that when he thought of becoming a father, he already pictured himself taking care of a five year old child.

In the case of women who were more attached to the nuclear family model and the idealization of motherhood and unconditional love mother and child, we found greater suffering and demand in the exercise of motherhood in these families $(3,4$ and 6$)$. In these cases, the husbands were more protective of women and made a point of emphasizing that they were good mothers and had a differentiated bond with the child. We also point out that, in cases where women had less idealization of motherhood, they were the ones who adopted a protective attitude towards their husbands (families 1, 5 and 8): the wives asked for permission/authorization to speak and to be corrected if they were wrong, but they showed no doubt that they were right, and were concerned to recognize/overvalue their participation with their children, as if they needed to be protected in this situation.

Thus, we find that motherhood is in a transition phase and that some women are unable to give up the idea of being the main references for their children (families 3, 4, 5 and 6), while others did not mention having this issue (families 1, 2, 7 and 8). On the other hand, the results showed that it is not the responsibility of women or men to establish egalitarian care or to break gender binarism in the parental exercise, but rather the responsibility of the couple linked to the current culture. Women need to make room for male participation and men must show interest and even fight for their caregiver position, which is not yet culturally accepted. In the social context, we emphasize that schools must be careful to attach importance to paternal participation in the schooling process, and companies must establish policies that legitimize and guarantee paternal participation in child care.

The recognition of paternal insertion is still incipient considering some social situations, from the daily situations to the most institutionalized ones, such as labor legislation that offers a few days of paternity leave. The report by the father of family 7 highlights this fact: when his wife got pregnant he looked for books that addressed parenting issues and found only pink covers addressed to "future moms." This situation is a reflection of a thought that recognizes and legitimates maternal care, but does not presuppose paternal interest and participation in the direct care of young children. As a consequence, men who want to take care of their babies feel inadequate, intrusive, or helpless in this role - after all, just as women seek support in books that report on the experience of other women and early childhood professionals about parenting, some men have already mentioned having this same need (families 7 and 8).

\section{Parental exercise and child care network}

The couples of this study showed a strong sense of loneliness in parenting. In this context, the participation of professionals - whether pediatricians or educators -, proved to be of great importance to families: as much as all participants mentioned having the participation of grandparents, we observe that this support occurs primarily on weekends (except in family 4) and is ambivalently experienced by women. 
That is, if on one hand they want to rely on their mothers to take care of their children, on the other hand they tend to disregard the advice they receive, as they consider them inadequate/outdated in relation to pediatricians' guidelines. In addition, the geographical distance and grandparents' own personal activities were also mentioned as impediments to a more frequent participation.

Regarding the direct child care network, only one baby entered the day care center immediately after the end of maternity leave (family 1). Two children did not attend day care at the time of the interview: family 2 stated that they did not consider it necessary to enroll their child before the age of three, as the mother was available at home to take care of the child, and family 6 stated that they did not intend to have their child enter school before the age of two, oriented by the pediatrician. The other families chose to enroll their children in day care even though they could afford to hire a nanny, believing that it would be important for their children to have contact with other children of the same age and to participate in activities directed by a professional who was specifically trained to deal with babies.

Regarding the participation of nannies, we verified that these professionals took care of the children of 4 of the interviewed couples (families 5, 6, 7 and 8), but this participation was characterized as a necessary support during the week to cover the absence of parents, for part-time periods, or to act as a backup to those who were at home taking care of the baby, usually the mother. Except for family 3, who had a nurse to help with the child's first 6 months of life, none of the other couples hired a nanny to stay overnight. Of the families that had the help of babysitters, we found that two of them replaced the care provided by these professionals with the service developed in day care centers (families 5 and 8).

The place assigned to the pediatrician by the interviewed families ranged from a technician who provided guidance in questions related to the physical health of children, to a counselor regarding issues of the physical and emotional development of the child and family. In four couples (families 4, 6, 7 and 8), pediatricians were called upon to deal with emotional issues in the parent-child relationship. In general, couples demanded confidence and acceptance in matters concerning the physical well-being of their children from the pediatrician, but if the doctor allowed or encouraged them to talk more about their experiences as parents, they were easily called upon to play a guiding role for questions regarding parental conduct, such as the ones regarding children's behavior.

Regarding the place occupied by school from the perspective of the interviewed families, we found that due to the fact that education professionals, for at least part-time, shared the daily care of the children with their parents, school was considered as a fundamental support for parenting. At school, children have the opportunity to live with different people and situations from those they are used to in the family environment, but career and work-related reasons were the main reasons that led parents, especially in the child's first year of life, to enroll their children in day care centers.

Of the six couples who had children attending school, we found that all families, except family 4 (which emphasized the importance of socialization), considered that school occupied a key place in the division of physical and emotional child care. In Family 1, the child was in a full time school, and the parents mentioned how important it was, especially in the first month, to be able to rely on the educators' guidance on how to organize the child's routine and for the mother to feel safe when returning to work.

Overall, parents who chose to enroll their children in day care centers highlighted how comforting it is to be able to rely on the support of educators/educational coordinators to discuss issues regarding their children's overall development and to share the tasks of caring and educating while they are working or engaging in personal activities - regardless of whether or not the parents of these children, who are under 3 years old, work outside the household. Their discourses suggested an understanding that caring is confined to the physical care of children and that educating concerns pedagogical and emotional activities (for example, 8 teaching the child to get along with others). 
The discourse of the interviewed families evidenced their consideration of preschool as something more than a substitute for maternal care. The importance of the child participating in different environments, ones different from the family environment, was emphasized, as this provides otherness experiences and contributes to their general development. It is worth noting that, for these parents, the school continues to share the educational and caregiving function with them.

The parents also pointed out that, in addition to feeling assured to know that they are not solely responsible for their children's education, because they have the attentive and specialized look of the educators, they are also favored by sharing the school place with other parents and children, as they have the opportunity to exchange information and understand if their children's development is going as expected. This last aspect was emphasized especially by couples who do not share any environments with other children, and therefore do not have any parameters to compare and to understand what is expected of a child at a certain age.

\section{Discussion}

In the contemporary world, faced with so many possibilities for the parental exercise (the mother can stay at home, or pursue a career like her husband - double career couples - or the father can choose to be at the forefront of child care) The attempt to reconcile personal fulfillment and parenting is a challenge for parents (Kosakowska-Berezecka, Beast, Adamska, Jaskiewicz, \& Jurek, 2016; Pereira, Vieira, \& Matos, 2017).

We consider that the ownership of parenting by parents can be discussed in two areas. In the first instance, we deal with the establishment of a kind of parental exercise which is centered only on the couple's members. In this case, we see parenting establishing itself in the midst of the coexistence of the nuclear family model - marked by the rigid division of roles based on gender differences - , and new models in which parental roles are exercised more flexibly, without the rigidity of roles previously assigned to men and women (Fiorin, Oliveira, \& Dias, 2014; Feijó, Júnior, Nascimento, \& Nascimento, 2017).

By contemporary or new models, we identified three possibilities: (a) model of greater fluidity in parental roles, with varying degrees of fluidity, in which a division of tasks similar to that of the nuclear family (the man as the provider and the woman as the caregiver) remains; (b) an egalitarian model of parental care, with a predominance, in the discourse of parents, of giving greater value to the maternal figure - that is, in which men and women, in practice, establish a division of responsibilities for caring for their children equally, but in the discourse they attach greater importance to the maternal figure regarding child care; and (c) a model of breaking with gender binarism in the parental exercise, but with a predominance of assigning responsibilities for child care in one of the spouses - where male and female do not necessarily establish an equal division of responsibilities for child care, but they attribute, in their discourse, a similar importance to the mother figure and the father figure in the care of the baby. The disruption of gender binarism in the parental exercise would thus occur to the extent that the maternal figure is not considered to be of major importance in taking care of young children.

The parental exercise of couples based on the existence of the otherness that marks the difference between the subjects - father and mother - is not assured by differences of biological sex or gender of individuals (Rehel, 2014; Stevens, 2015). In the heterosexual family, although gender difference seems to be a factor in the issue of otherness, we cannot assume that the difference between individuals is given only because they are members of a couple composed of a man and a woman. We rely on the otherness as the possibility for individuals to exercise parenting creatively - which, in Winnicott's terms, would give sense to existence and make us realize that we are living our own lives, with all the experiences of anguish and dissatisfaction that life brings, necessarily. 
If within a couple we can describe three ways of parenting appropriation, in a second sphere we can understand the participation of the child care network in the establishment of the parental exercise. In the present study we limit ourselves to the child care network composed of pediatricians and kindergarten professionals and observed that, in general, the network is seen as a possibility of holding (Winnicott, 1987/2006) to the parental holding. The position that pediatricians and the school professionals occupy within the parental exercise, however, retain specificities, both in the nature and in the frequency of child care with which they participate in the daily lives of families.

Pediatricians may assume a guiding role that provides information to parents while also supporting parenting, taking into account the characteristics of each family (Dickstein, Verztman, Dias, \& Andrade, 2017). Medical knowledge is viewed by couples as specialized knowledge, but each family relates to this knowledge in their own way - that is, while some couples may delegate or outsource child-related knowledge to the doctor, others establish trust, share care, but also take into consideration their own knowledge about the child (Carvalho \& Martins Filho, 2015).

Nowadays, considering the advances in technology, parents have easier access to the pediatrician, and while this fact can facilitate the reception and resolution of an urgent issue, on the other, it can make it difficult for the parental couple to learn how to cope with their own anguish, and make it difficult for them to perfect their parental exercise.

Kindergartens, in turn, support the parenting process, but they also take care of daily child care. We know that there are cases of parents who delegate child care practices to their child's educators, outsourcing this care, but we found no such family in this context.

As for the sharing of child care practices, the school finds several possibilities of positioning in the child care network. For parents of children under the age of one, the school may take the place of a momentary surrogate for parental functions - that is, to subjectivize the baby by supporting the functions necessary for the constitution of the subject during the period when the parents are absent (Grande, Nunes, Coelho, Cadima, \& Barros, 2017).

For parents of children over the age of one, the school may occupy the position of both a counselor on parenting issues and a partner in child care. Finally, either through the staff working there, or because it provides contact with other families, the school offers the possibility for the child be inserted in the local culture, thus configuring the school as a third party in the relationship between the child and the parents.

We identified in the discourse of parents, pediatricians and educational coordinators that the notion of care offered to children from 0 to 3 years old, today, is understood as a possibility for children to be seen as individuals who need affection, stimulation and parental care. However, in the eagerness of parents to provide this care, children may be subject to some paradoxes, such as parental overinvestment - which, on the one hand, protects the child, on the other, may diminish autonomy and self-confidence.

Another situation is that of more democratic parents, but at the same time more anguished in trying to be up to the various demands arising from parental, marital and individual spheres. In this sense they may find it difficult to frustrate the child and impose rules and limits, either because they are tired after a long day at work, because they feel that their little time with the child should be pleasant, or because they confuse authority with authoritarianism, and end up not being consistent in their actions with their children (Zanetti \& Gomes, 2009).

Among the changes that are necessary so that egalitarian parental care can be understood and exercised by couples, we highlight that psychoanalytic concepts, such as the Winnicott formulation of the primary maternal concern (Winnicott, 1956/2000), are revised to contemplate not only the experience of motherhood, but to contemplate the male experience as well (Campana, Santos, \& Gomes, 2019; Moraes, 2017) and the exchange of roles between fathers and mothers. 
Our suggestion is that future studies address the repercussion that the multiplicity of the exercise of contemporary parenting brings to the emotional development of children. For example, a comparative study between the development of children going to the nursery, of children who are cared for by nannies and of children who are cared for by one of their parents. We also suggest further studies focused on understanding the emotional development of babies, children of heterosexual couples, but who are primarily cared for by the father.

We hope that this research will help professionals (psychologists, pediatricians and educators) who are concerned not only with young children, but also with adults who are or want to be parents, to recognize the anguish involved in contemporary parenting and to support individuals seeking to make more conscious choices that favor not only the creative parenting experience, but perhaps the emotional development of children as well.

\section{Contributors}

N.T.C. CAMPANA wrote the article. I.C. GOMES was the supervisor of the thesis that originated the presente article and contributed to the discussion of the results, as well as to the general review of the article.

\section{References}

Aching, M. C., \& Granato, T. M. M. (2018). Role of a support network for refugee mothers. Estudos de Psicologia (Campinas), 35(2), 137-147. http://dx.doi.org/10.1590/1982-02752018000200003

Amazonas, M. C. L. A., Vieira, L. L. F., \& Pinto, V. C. (2011). Modos de subjetivação femininos, família e trabalho. Psicologia: Ciência e Profissão, 31(2), 314-327. http://dx.doi.org/10.1590/S1414-98932011000200009

Badinter, E. (2011). O conflito: a mulher e a mãe. Rio de Janeiro: Record.

Bardin, L. (1977). Análise de conteúdo. Lisboa: Edições 70.

Biffi, M., \& Granato, T. M. M. (2017). Projeto de ter filhos: uma revisão da literatura científica nacional e internacional. Temas em Psicologia, 25(1), 207-220. http://dx.doi.org/10.9788/TP2017.1-14Pt

Campana, N. T. C., \& Gomes, I. C. (2017). O exercício parental contemporâneo e a rede de cuidados com a primeira infância. Psicologia em Estudo, 22(3), 449-460. http://dx.doi.org/10.4025/psicolestud.v22i3.35067

Campana, N. T. C., Santos, C. V. M., \& Gomes, I. C. (2017). Cuidado parental igualitário: modelo de relação pais-bebê no contemporâneo? In M. A. Santos, D. Bartholomeu, \& J. M. Montiel. Relaçôes interpessoais no ciclo vital: conceitos e contextos (pp.37-47). São Paulo: Vetor.

Campana, N. T. C., Santos, C. V. M., \& Gomes, I. C. (2019). De quem é a preocupação primária? A teoria winnicottiana e o cuidado parental na contemporaneidade. Psicologia Clínica, 31(1), 30-52.

Carvalho, S., \& Martins Filho, J. (2016). Family relationships with pediatricians: The maternal views. Revista Paulista de Pediatria, 34(3), 330-335. http://dx.doi.org/10.1016/j.rppede.2016.03.015

Chodorow, N. (2002). Psicanálise da maternidade: uma crítica a Freud a partir da mulher. Rio de janeiro: Rosa dos Tempos. (Originalmente publicado em 1978).

Dickstein, P., Verztman, J. S., Dias, D. R. B., \& Andrade, B. P. (2017). O pediatra e sua função apostólica: percepções de médicos residentes sobre suas práticas. Psicologia em Estudo, 22(2), 209-220. http://dx.doi.org/10.4025/psicolestud. v22i2.32552

Feijó, M. R., Júnior, E. G., Nascimento, J. M., \& Nascimento, N. B. (2017). Conflito trabalho-família: um estudo sobre a temática no âmbito brasileiro. Pensando Famílias, 21(1), 105-119. Recuperado em julho 26 2018, de http://pepsic. bvsalud.org/scielo.php?script=sci_arttext\&pid=S1679-494X2017000100009\&lng=pt\&tlng=pt

Fiorin, P. C., Oliveira, C. T., \& Dias, A. C. G. (2014). Percepções de mulheres sobre a relação entre trabalho e maternidade. Revista Brasileira de Orientação Profissional, 15(1), 25-35. Recuperado em julho 26, 2018, de http://pepsic.bvsalud. org/scielo.php? script=sci_arttext\&pid=\$1679-33902014000100005\&lng=pt\&tIng=pt

Freud, S. (1996). Moral sexual civilizada e doença nervosa moderna. In S. Freud, Edição Standard Brasileira das obras completas de Sigmund Freud (Vol. 9, pp.169-190). Rio de Janeiro: Imago. (Originalmente publicado em 1908). 
Gomes, I. C., \& Levy, L. (2009). O mal-estar e a complexidade da parentalidade contemporânea. Cadernos de Psicanálise, 23(28), 217-238. Recuperado em julho 26, 2018, de http://spcrj.org.br/admin/data/pdf/2009.pdf

Grande, C. R., Nunes, I. B., Coelho, V., Cadima, J., \& Barros, S. (2017). A experiência do bebê na creche: percepções de mães e de educadoras no período de transição do contexto familiar para a creche. Análise Psicológica, 35(3), $247-262$. http://dx.doi.org/10.14417/ap.1174

Kosakowska-Berezecka, N., Besta, T., Adamska, K., Jaskiewicz, M., Jurek, P., Jurek, P., \& Vandello, J. A. (2016). If my masculinity is threatened I won't support gender equality? The role of agentic self-stereotyping in restoration of manhood and perception of gender relations. Psychology of Men \& Masculinity, 17(3), 274-284. http://dx.doi. org/10.1037/men0000016

Lima, N. L., \& Rezende, A. O. (2013). O poder normativo nas escolas e seus efeitos sobre os sujeitos. Estilos da Clínica, 18(1), 34-52.

Martins Filho, J. (2008). A criança terceirizada: os descaminhos das relações familiares no mundo contemporâneo. Campinas: Papirus.

Moraes, C. J. A. (2017). Tornando-se pai: narrativas de casais grávidos sobre a transição para a paternidade (Tese de doutorado não-publicada). Pontifícia Universidade Católica de Campinas.

Oliveira, G. P., Passos, M. S., Leal, E. S., \& Nascimento, D. C. (2013). A peregrinação messiânica de casais inférteis pelas clínicas de reprodução humana assistida. Pensando Famílias, 17(1), 17-27. Recuperado em julho 26, 2018, de http:// pepsic.bvsalud.org/scielo.php?script=sci_arttext \&pid=S1679-494X2013000100003\&lng=pt\&tlng=pt

Pereira, A. V., Vieira, J. M., \& Matos, P. M., (2017). Interface trabalho-família, vinculação romântica e parentalidade. Análise Psicológica, 35(1), 73-90. http://dx.doi.org/10.14417/ap.1071

Rehel, E. M. (2014). When dad stays home too: Paternity leave, gender, and parenting. Gender \& Society, 28(1), 110-132. http://dx.doi.org/10.1177/0891243213503900

Santos, C. V. M., \& Antúnez, A. E. A. (2018). "Papai não tem leite!” considerações sobre o holding paterno na dependência absoluta. Psicologia em Estudos, 23, 103-114.

Santos, C. V. M., Campana, N. T. C., \& Gomes, I. C. (in press). Cuidado parental igualitário: revisão de literatura e construção conceitual. Psicologia: Teoria e Pesquisa.

Stevens, E. (2015). Understanding discursive barriers to involved fatherhood: the case of Australian stay-at-home fathers. Journal of Family Studies, 21(1), 22-37. http://dx.doi.org/10.1080/13229400.2015.1020989

Turato, E. R. (2003). Tratado metodológico da pesquisa clínico-qualitativa: construção teórico-epistemológica, discussão comparada e aplicação nas áreas da saúde humana. Petrópolis: Vozes.

Vorcaro, A., \& Ferreira, T. (2014). Entre o capricho e o anonimato, quem são os pais de hoje? In R. Voltolini (Org.), Retratos do mal-estar contemporâneo na educação (pp.15-22). São Paulo: Escuta.

Winnicott, D. W. (2000). A preocupação materna primária. In D. W. Winnicott, Da Pediatria à Psicanálise: obras escolhidas (pp.399-405). Rio de Janeiro: Imago. (Originalmente publicado em 1956).

Winnicott, D. W. (2006). Os bebês e suas mães. São Paulo: Martins Fontes. (Originalmente publicado em 1987).

Zanetti, S. A. S., \& Gomes, I. C. (2009). A ausência do princípio de autoridade na família contemporânea brasileira. Psico - PUCRS, 40(2), 194-201. Recuperado em julho 26, 2018, de http://revistaseletronicas.pucrs.br/ ojs/index.php/ revistapsico/article/view/3726

Received: March 21, 2019

Final version: June 13, 2019

Approved: September 17, 2019 